\title{
Kebijakan Pengelolaan Ruang Terbuka Hijau di Kota Makassar
}

\author{
Hamrun $^{1}$ dan A. Luhur Prianto ${ }^{2}$ \\ 1hamrun07@gmail.com dan ${ }^{2}$ luhur gov@yahoo.com
}

\begin{abstract}
ABSTRAK
Tujuan penelitian ini untuk mengetahui dan mengalisis upaya Pemerintah Kota Makassar dalam mengoptimalkan kebijakan pengelolaan ruang terbuka hijau (RTH) dengan berbagai Stakeholder di Kota Makassar. Penelitian ini adalah tergolong pada jenis penelitian deskriptif, sementara pendekatan yang digunakan adalah pendekatan kualitatif, Penelitian ini dilakukan di Kota Makassar Provinsi sulawesi selatan. informan pada penelitian ini ialah: Pemerintah Kota Makassar (Dinas Pertamanan dan kebersihan Kota Makassar). Masyarakat Kota Menetap (Masyarakat Ilmiah/Perguruan Tinggi,Masyarakat profesional dan Masyarakat umum Kota Menetap), Swasta (pengusaha yang memanfaatkan lahan terbuka hijau), Pengguna Taman kota, Media Massa. Jumlah keseluruhan informan pada penelitian ini sebanyak 8, dengan klasifikasi sebagai berikut : 8 orang sebagai informan Kunci. Datadata penelitian diperoleh dari berbagai sumber data guna menjawab permasalahan penelitian, yaitu : data primer dan data sekunder. Pengumpulan data dilakukan melalui observasi langsung dan wawancara. Teknik analisa data yang dipakai dalam penelitian ini adalah deskriptif kualitatif.

Hasil penelitian menunjukan upaya Pemerintah Kota Makassar dalam mengoptimalkan kebijakan pengelolaan ruang terbuka hijau (RTH) dengan berbagai Stakeholder di Kota Makassar seperti Pemerintah, Swasta, Pengguna Taman, dan media Massa sudah terjalin dengan baik. Kata kunci : Kebijakan, Pengelolaan, Ruang Terbuka Hijau
\end{abstract}

\section{LATAR BELAKANG PENELITIAN}

Isu mengenai masalah lingkungan hidup semakin menjadi bahasan yang sangat menarik dewasa ini. Salah satu permasalahan yang kini dihadapi oleh hampir seluruh perkotaan di Indonesia adalah semakin berkurangnya lingkungan dan ruang publik. Terutama ruang terbuka hijau, kota-kota besar pada umumnya memiliki ruang terbuka hijau dengan luas dibawah $10 \%$ dari luas kota itu sendiri. Kondisi tersebut sangat jauh dibawah ketentuan pemerintah pada UU No. 26 Tahun 2007 tentang ruang terbuka hijau yang mewajibkan pengelola perkotaan yang menyediakan ruang terbuka hijau publik dengan luas sekitar $20 \%$ dari luas kota tersebut. Fungsi Ruang Terbuka Hijau Tampaknya masih mempunyai 
makna pelengkap/penyempurna bagi perkotaan sehingga pemanfaatan lahan untuk ruang terbuka hijau dianggap sebagai penambah estetika lingkungan, lebih parah lagi ruang terbuka Hijau dianggap sebagai candaan untuk penggunaan lahan dimasa mendatang. Hal ini mengakibatkan munculnya paradigma bahwa setiap saat ruang terbuka hijau dapat diganti dengan penggunaan lain, yang dirasakan lebih menguntungkan secara ekonomis. (Sugandhy \& Aca, 2009)

Masalah Ruang Terbuka Hijau (RTH) di Perkotaan saat ini merupakan salah satu masalah yang sulit untuk dipecahkan di Kota-kota besar. Masalah RTH terjadi karena adanya kebutuhan ruang untuk menampung penduduk dan aktivitasnya, sehingga ruang hijau tersebut cenderung mengalami konversi guna lahan menjadi kawasan terbangun yang dilakukan tanpa memperhatikan keberadaan lingkungan sekitar. Sebagian besar permukaannya, terutama di pusat kota, tertutup oleh jalan, bangunan dan lain-lain dengan karakter yang sangat kompleks dan berbeda dengan karakter ruang terbuka hijau. Pada umumnya dapat mengakibatkan terjadinya penurunan kualitas dan kuantitas lingkungan hidup. Menurunnya kuantitas dan kualitas ruang terbuka publik yang ada di perkotaan, baik berupa ruang terbuka hijau (RTH), telah mengakibatkan menurunnya kualitas lingkungan perkotaan seperti seringnya terjadi banjir di perkotaan, tingginya polusi udara, dan meningkatnya kerawanan sosial (kriminalitas dan krisis sosial), menurunnya produktivitas masyarakat akibat stress karena terbatasnya ruang publik yang tersedia untuk interaksi sosial. Dengan kata lain, keberadaan RTH dapat mengendalikan dan memelihara integritas dan kualitas lingkungan, karena Ruang Terbuka Hijau mempunyai tujuan dan manfaat yang besar bagi keseimbangan, kelangsungan, kesehatan, kelestarian, dan peningkatan kualitas lingkungan itu sendiri. Saat ini pentingnya membagun kota hijau di tegah kota oleh karena itu kebijakan mendasar dan komitmen kuat untuk membagun yang memungkinkan kota berkelanjutan (kota hijau). Pendekatan pembagunan kota hijau harus dilaksanakan dengan pengombinasikan pertumbuhan ekonomi sehat dan ramah lingkungan (pro 
green growth), meningkatkan kesejatraan masyrakat (pro poor), menyediakan lapangan kerja yang ramah lingkungan (pro green jobs), dan dalam bingkaian menjaga kelestarian lingkunggan (pro evironment) kota hijau adalah kota yang di banguun dengan ke unggulan indonesia yang memiliki iklim tropis serta keunukan ekosistem, dan kota hijau merupakan kota sehat dan bersahabat ( Nirwono Joga, 2011:3 ).

Perkembangan kawasan perkotaan yang sedemikian cepat harus dibarengi oleh peningkatan kapasitas pemangku kepentingan untuk mempertahankan kualitas lingkungan kehidupan perkotaan. Penyediaan prasarana dan sarana hampir selalu tertinggal oleh perkembangan permasalahan yang terjadi. Kemampuan pengelola perkotaan dalam memahami permasalahan yang timbul dan merumuskan upaya pemecahannya belum juga menunjukkan hasil positif yang mengarah pada perbaikan kualitas lingkungan perkotaan. Saat ini sangat sulit menemukan perkotaan yang perkembangannya diindikasikan oleh hal-hal positif. Perkembangan yang kasat mata dan mudah dikenali justru hal-hal yang tidak semestinya terjadi seperti berkurangnya ruang terbuka hijau, kemacetan dan kesemrawutan lalu lintas, polusi, pengelolaan limbah yang tidak tuntas, serta sifat individualistis masyarakatnya. Perencanaan tata ruang dalam konteks pengalokasian $\mathrm{RTH}$ seyogyanya dilakukan dengan mempertimbangkan keserasian, keselarasan, dan keseimbangan fungsi budi daya dan fungsi lindung sebagaimana amanat UU No. 26 Tahun 2007 Tentang Penataan Ruang. Ketidakmampuan menyeimbangkan kedua fungsi tersebut menunjukkan lemahnya komitmen politik tata ruang. Kegagalan politik tata ruang dapat diukur dari kurangnya keinginan untuk membiayai program RTH (green budgeting RTH). Berdasarkan KTT Bumi di Rio de Jeneiro alokasi ruang terbuka hijau suatu kawasan perkotaan adalah $30 \%$ dari luas kota.

Ruang Terbuka Hijau, Mengembangkan kawasan hijau binaan kawasan pusat kota di targetkan 5\% (lima persen) dari kawasan pusat kota: Melestarikan taman-taman dikawasan pusat penukiman seperti halnya Taman-taman Kota serta meningkatkan RTH kawasan Olahraga 
terpadu (Perda Kota Makassar No 6 Tahun 2006 ). Dengan seiringnya waktu dan perkembangan zaman yang semakin pesat dan laju pertumbuhan ekonomi yang begitu cepat serta meningkatnya kebutuhan soaial, baik dari segi pergaulan kehidupan dan kebutuhan yang akhirnya mengeserkan ataupun mengalih fungsikan lahan-lahan kawasan hijauh terpadu di kawasan perkotaan, sehingga kawasan hijau teralih fungsikan, Ruang terbuka hijau yang ideal adalah $30 \%$ dari luas wilayah. Hampir disemua kota besar di Indonesia, Ruang terbuka hijau saat ini baru mencapai $10 \%$ dari luas Kota. Padahal ruang terbuka hijau diperlukan untuk kesehatan, arena bermain, olah raga dan komunikasi publik. Pembinaan ruang terbuka hijau harus mengikuti struktur Nasional atau Daerah dengan standar-standar yang ada.

Melihat kecenderungan pertumbuhan penduduk Kota Makassar yang sangat pesat maka masalah kepadatan penduduk meningkat, sehingga dengan bertambahnya penduduk kota akan menuntut pertambahan pada kebutuhan tempat yang nyaman untuk tinggal dan kota yang bersih dan hijau. Suatu kondisi yang harus diwujudkan bagi organisasi pemerintah kota di tengah dinamika kependudukan yang menuntut pemenuhan sarana produksi demi pergerakan dan akumulasi kapital secara dinamis.

Pada titik inilah sangat urgen dan diperlukan Kehadiran Negara dalam hal ini Pemerintah Kota Makassar, sebagai sebuah organisasi publik, untuk mengambil peran yang sangat penting dalam pengelolaan ruang terbuka hijau di kota Makassar dan mengimplementasikan kebijakan penata ruang kota, terutama konsistensi dalam menjalankan ketentuan akan penyediaan ruang terbuka hijau, yang dapat mengakomodasikan kepentingan seluruh elemen masyarakat. Dengan kebijakan tersebut, diharapkan senergi antara Pemerintah, Pengusaha swasta, masyarakat dan media Massa dapat menciptakan keselarasan dalam percepatan pembangunan. Diharapkan pula, manusia sebagai subjek dan objek kebijakan yang dinamis mampu menciptakan berbagai alternative dalam menghadapai dinamika organisasi keruangan kota. 
Untuk keberhasilan pengelolaan ruang terbuka hijau di kota Makassar tentunya pelaku-pelaku pengelolaan terbuka hijau harus terlibat dalam perencanaan/pengendalian, kelembagaan/pengorganisasian, Sumber Daya Manusia, Kordinasi dan Pendanaan.

Jumlah taman yang ada di Kota Makassar menurut data UPTD Pengelolaan Lapangan Dan Taman Kota Makassar adalah sebanyak 28 buah, baik yang masih terurus hingga kini maupun yang sudah tidak terurus lagi. Keseluruhan taman ini tersebar di empat arah mata angin kota. Belum maksimalnya pengelolaan taman merupakan faktor utama pemicu berkurangnya minat masyarakat untuk menggunakan taman. Upaya pemerintah kota makassar dalam hal ini dinas pertamanan dan kebersihan kota makassar untuk mengembalikan fungsi taman dan bisa menarik lagi minat masyarakat tentunya sangat diperlukan sebagai penanggungjawab pengelola taman di kota Makassar. perlu disadari bahwa dalam pengelolaan taman kota bukan hanya wewenang pemerintah kota makassar saja akan tetapi peran swasta dan pengguna taman juga perlu dilibatkan. Olehnya itu dinas pertamanan dan kebersihan kota makassar perlu melakukan kerja sama dengan pihak swasta untuk menghadirkan taman yang nyaman untuk dinikmati oleh masyarakat seperti yang sudah dilakukan dikota-kota besar lainnya seperti surabaya.

Untuk mewujudkan Pengelolaan Taman Kota secara maksimal di Kota Makassar tentunya diperlukan peran pemerintah agar membangun relasi dengan pihak Swasta dan Masyarakat dalam pengelolaan Taman di Kota Makassar. Pemerintah kota Makassar harus mampu melakukan upaya-upaya politik untuk mensinergikan semua stakeholders yang terlibat dalam pengelolaan Taman di Kota Makassar

Berdasarkan urian diatas dan berbagai fenomena yang ada penulis tertarik melakukan penelitian mengenai" Kebijakan pengelolaan Ruang terbuka hijau (RTH) di kota Makassar". 


\section{Rumusan Masalah Penelitian}

Adapun yang menjadi rumusan masalah dalam penelitian itu yaitu bagaimana upaya Pemerintah Kota Makassar dalam mengoptimalkan kebijakan pengelolaan ruang terbuka hijau (RTH) dengan berbagai Stakeholder di Kota Makassar.

\section{Maksud dan Tujuan Penelitian}

Maksud dan Tujuan Penelitian ini yaitu untuk mengetahui dan mengalisis upaya Pemerintah Kota Makassar dalam mengoptimalkan kebijakan pengelolaan ruang terbuka hijau (RTH) dengan berbagai Stakeholder di Kota Makassar.

\section{Kegunaan Penelitian}

Dengan mendasarkan pada rumusan permasalahan maka, dalam penelitian ini mengharapkan dapat memberikan kegunaan dalam hal:

Yang dimaksud dengan kegunaan praktis ini adalah keseluruhan data dan informasi yang disajikan dalam bentuk laporan hasil data penelitian ini diharapkan mampu memberikan masukan bagi pemerintah kota Makassar dalam bidang pengelolaan Taman Kota, di Kota Makassar.

1. Hasil penelitian ini diharapkan dapat memberikan kontribusi bagi pengembangan ilmu pengetahuan, khususnya mengenai Kebijakan Pengelolaan Ruang Terbuka Hijau (RTH) di Kota Makassar.

2. Sebagai salah satu bahan referensi bagi peneliti lainnya yang berminat meneliti masalah-masalah Pengelolaan Taman kota.

\section{KAJIAN PUSTAKA}

\section{Kebijakan Publik}

Dalam Kamus Besar Bahasa Indonesia, kebijakan diartikan sebagai rangkaian konsep dan asas yang menjadi garis besar dan dasar rencana dalam pelaksanaan suatu pekerjaan, kepemimpinan, dan cara bertindak (tentang pemerintahan, organisasi, dsb); pernyataan cita-cita, tujuan, prinsip dan garis pedoman untuk manajemen dalam usaha mencapai sasaran kebijakan sebagai serangkaian tindakan/kegiatan yang diusulkan 
seseorang, kelompok atau pemerintah dalam suatu lingkungan tertentu dimana terdapat hambatan-hambatan (kesulitan-kesulitan) dan kesempatan-kesempatan terhadap pelaksanaan usulan kebijaksanaan tersebut dalam rangka mencapai tujuan tertentu. ide kebijakan melibatkan perilaku yang memiliki maksud dan tujuan merupakan bagian yang penting dari definisi kebijakan, karena bagaimanapun kebijakan harus menunjukan apa yang sesungguhnya dikerjakan daripada apa yang diusulkan dalam beberapa kegiatan pada suatu masalah Car J Federick (Leo Agustino, 2008:7).

Lingkup dari studi kebijakan publik sangat luas karena mencakup berbagai bidang dan sektor seperti ekonomi, politik, sosial, budaya, hukum, dan sebagainya. Disamping itu dilihat dari hirarkirnya kebijakan publik dapat bersifat nasional, regional maupun lokal seperti undangundang, peraturan pemerintah, peraturan presiden, peraturan menteri, peraturan pemerintah daerah/provinsi, keputusan gubernur, peraturan daerah kabupaten/kota, dan keputusan bupati/walikota. Secara terminologi pengertian kebijakan publik (public policy) itu ternyata banyak sekali, tergantung dari sudut mana kita mengartikannya. Easton memberikan definisi kebijakan publik sebagai the authoritative allocation of values for the whole society atau sebagai pengalokasian nilai-nilai secara paksa kepada seluruh anggota masyarakat. Laswell dan Kaplan juga mengartikan kebijakan publik sebagai projected program of goal, value, and practice atau sesuatu program pencapaian tujuan, nilai-nilai dalam praktek-praktek yang terarah. kebijakan publik sebagai hipotesis yang mengandung kondisi-kondisi awal dan akibat-akibat yang bias diramalkan, Pressman dan Widavsky (Budi Winarno 2002: 17). Kebijakan publik itu harus dibedakan dengan bentuk-bentuk kebijakan yang lain misalnya kebijakan swasta. Hal ini dipengaruhi oleh keterlibatan faktor-faktor bukan pemerintah. Robert Eyestone sebagaimana dikutip Leo Agustino (2008:6) mendefinisikan kebijakan publik sebagai hubungan antara unit pemerintah dengan lingkungannya. 


\section{Ruang Terbuka Hijau}

Ruang terbuka hijau adalah area memanjang/jalur dan/atau mengelompok, yang penggunaannya lebih bersifat terbuka, tempat tumbuh tanaman, baik yang tumbuh secara alamiah maupun yang sengaja ditanam (Undang-Undang Penataan Ruang No 26 Tahun 2007 pasal 29 ayat 1$)$.

Beberapa pengertian RTH disampaikan oleh beberapa ahli, diantaranya adalah :

1. Ruang yang didominasi oleh lingkungan alami di luar maupun di dalam kota, dalam bentuk taman, halaman, areal rekreasi kota dan jalur hijau (Traneik, 1986;61).

2. Pembentukan RTH Kawasan Perkotaan disesuaikan dengan bentang alam berdasarkan biogografis dan struktur ruang kota serta estetika, dan jenis RTH Kawasan Perkotaan : taman kota, taman wisata, taman rekreasi, taman lingkungan perumahan / pemukiman, taman lingkungan perkantoran / gedung, taman hutan raya, hutan kota, hutan lindung, bentang alam (gunung, bukit, lereng dan lembah), cagar alam, kebun raya, kebun binatang, pemakaman umum, lapangan olahraga, lapangan upacara, parkir terbuka, lahan pertanian perkotaan, jalur di bawah tegangan tinggi (sutt dan sutet), sempadan (sungai, pantai, bangunan, situ dan rawa), jalur pengamanan (jalan, median jalur rel kereta api, pipa gas dan pedestrian), kawasan dan jalur hijau, daerah penyangga (buffer zone) lapangan udara, dan roof garden (Permendagri no. 1 Tahun 2007).

3. Fasilitas yang memberikan kontribusi penting dalam meningkatkan kualitas lingkungan permukiman, dan merupakan suatu unsur yang sangat penting dalam kegiatan rekreasi (Rooden Van PC dalam Grove dan Gresawell, 1983).

RTH membutuhkan perencanaan yang lebih baik lagi untuk menjaga keseimbangan kualitas lingkungan perkotaan. Mempertahankan lingkungan perkotaan agar tetap berkualitas merupakan penjabaran asas trilogy pembangunannya yaitu pertumbuhan ekonomi, pemerataan pembangunan dan hasil-hasilnya, dan stabilitas nasional melalui pembanguan berkelanjutan gvbfnhijj(sustainable development) dengan memperhatikan kelestarian lingkungan hidup. Proporsi 30 (tiga puluh) persen merupakan ukuran minimal untuk menjamin keseimbangan ekosistem kota, baik keseimbangan sistem hidrologi dan system mikroklimat, maupun sistem ekologis lain, yang selanjutnya akan 
meningkatkan ketersediaan udara bersih yang diperlukan masyarakat, serta sekaligus dapat meningkatkan nilai estetika kota. Untuk lebih meningkatkan fungsi dan proporsi ruang terbuka hijau di kota, pemerintah, masyarakat, dan swasta didorong untuk menanam tumbuhan di atas bangunan gedung miliknya (Undang-Undang Penataan Ruang No 26 Tahun 2007 pasal 29 ayat 2). Proporsi ruang terbuka hijau publik seluas minimal 20 (dua puluh) persen yang disediakan oleh pemerintah daerah kota dimaksudkan agar proporsi ruang terbuka hijau minimal dapat lebih dijamin pencapaiannya sehingga memungkinkan pemanfaatannya secara luas oleh masyarakat (Undang-Undang Penataan Ruang No 26 Tahun 2007 pasal 29 ayat 3).

\section{Pengelolaan Ruang Terbuka Hijau}

Pengelolaan kota dapat digambarkan sebagai sekumpulan kegiatan yang bersama-sama membentuk dan mengarahkan pada bidang sosial, fisik dan perkembangan ekonomi kota (Hakim, 2008 : 29). Pengelolaan ruang terbuka hijau akan memberi pengaruh terhadap perubahan kualitas dan kuantitas, sebagaimana teruraikan dalam penelitian Halle yang menunjukkan bahwa tidak mudah untuk memperbaiki strategi kelembagaan perkotaan dan mempunyai output yang terukur. Terdapat beberapa aspek dalam pengelolaan RTH (Hakim, 2008 : 32) yaitu perencanaan, kelembagaan, sumber daya manusia, koordinasi dan pendanaan

\section{Interaksi Stakeholders Dalam Pengelolaan Ruang terbuka Hijau (RTH) Kota}

Secara Umum pengelolaan merupakan terjemahan dari manajemen yang mencakup beberapa kegiatan, yakni perencenaan, pengendalian, kelembagaan/pengorganisasian, sumber daya manusia, kordinasi dan pendanaan. Pelaku-pelaku atau Stakeholders dalam pengelolaan ruang terbuka Hijau kota adalah sebagai Berikut: pemerintah, swasta, masyarakat kota dan media massa. 


\section{Taman Kota}

Taman kota merupakan sebidang lahan yang ditata sedemikian rupa, sehingga mempunyai keindahan, kenyamanan dan keamanan bagi pemiliknya atau penggunanya. Kota-kota di negara maju lebih mengutamakan taman kota untuk tujuan rekreasi dan sekaligus untuk menyegarkan kembali badan dan pikiran setelah bekerja lama dan terjadi kejenuhan. Taman kota merupakan fasilitas yang memberikan kontribusi penting dalam meningkatkan kualitas lingkungan permukiman, dan nampaknya merupakan suatu unsur yang penting bagi kegiatan rekreasi (Arifin \& Nurhayati, 1996:1). Taman kota pada awalnya memiliki dua fungsi utama yaitu:

a. Memberikan kesempatan rekreasi bagi masyarakat kota, aktif maupun pasif

b. Memberikan efek visual dan psikologis yang indah dalam totalitas ruang kota.

Dalam perkembangannya, taman kota tidak lagi terbatas untuk menampung kegiatan santai dan piknik saja, tetapi harus dapat menampung kegiatan-kegiatan lain secara maksimal seperti rekreasi aktif, olah raga, kegiatan kebudayaan, hiburan dan interaksi sosial. Karenanya, suatu taman kota memiliki berbagai fungsi yakni ekologis, biologis, hidrologis, estetis, rekreasi dan sosial.

Landasan teori taman kota yang dibahas tentang: elemen-elemen taman kota, fungsi taman kota, persyaratan taman kota. Penjelasan landasan teori taman kota akan memperjelas konsep taman kota. Dengan teori taman kota ini menjadi landasan dalam pembahasan terkait dengan taman kota, untuk mempermudah evaluasi dan identifikasi taman kota.

a. Elemen-elemen Taman Kota

Taman (garden) diterjemahkan dari bahasa Ibrani, "gan" berarti melindungi atau mempertahankan lahan yang ada dalam suatu lingkungan berpagar," oden" berarti kesenangan, kegembiraan, dan kenyamanan. Secara lengkap dapat diartikan taman adalah sebidang lahan berpagar yang digunakan untuk mendapatkan kesenangan, 
kegembiraan, dan kenyamanan. Taman kota secara tradisioanal merupakan alun-alun dan taman raja, pamong praja yang terbuka juga untuk umum. Baru pada zaman modern dengan perancangan tata kota, taman kota merupakan tempat umum yang dikehendaki masyarakat untuk beristirahat dekat perumahan dan sebagai pengatur iklim di kampung (Mulyani, 2006: 97).

Taman diartikan sebagai sebidang tanah terbuka dengan luasan tertentu di dalamnya ditanami pepohonan, perdu, semak, dan rerumputan yang dapat dikombinasikan dengan kreasi dari bahan lainnya. Taman (Landscape) adalah wajah dan karakter atau tapak bagian muka bumi dengan segala kehidupan dan apa saja yang ada di dalamnya, baik yang bersifat alami maupun buatan manusia, yang merupakan bagian atau total lingkungan hidup manusia beserta makhluk hidup lainnya, sejauh mata memandang, sejauh segenap indera dapat menangkap, dan sejauh imajinasi dapat membayangkan.

Menurut Peraturan Menteri Pekerjaan Umum Nomor 05/PRT/M/2008, dinyatakan bahwa Ruang Terbuka Hijau (RTH) taman kota adalah taman untuk melayani penduduk kota atau bagian dari wilayah perkotaan. Taman kota ini dapat melayani minimal 480.000 penduduk dengan stándar minimal 144.000 m2. Taman kota ini merupakan lapangan hijau yang dilengkapi dengan fasilitas rekreasi, dan olahraga dengan minimal RTH $80 \%$ - 90\%. RTH taman kota dapat dimanfaatkan penduduk untuk melakukan berbagai kegiatan sosial pada satu kota atau bagian wilayah kota yang dilengkapi dengan fasilitas olahraga, taman bermain anak dan balita, fasiltas rekreasi, taman khusus lansia, taman bunga, semua fasilitas ini terbuka untuk umum.

Berdasarkan aktifitasnya taman kota dikatagorikan atas 3 (tiga) macam, yaitu: taman untuk rekreatif aktif, taman untuk rekreatif pasif, dan taman untuk rekreatif pasif maupun aktif. Taman untuk rekreatif aktif Taman adalah taman yang didalamnya dibangun suatu kegiatan pemakai taman, sehingga pemakai taman secara aktif mengunakan fasilitas didalamnya, sekaligus memperoleh kesenangan, kesegaran dan 
kebugaran. Contohnya adalah taman olahraga, aerobic, fitness, camping ground, taman bermain anak, taman jalur jalan, kebun binatang, danau, pemancingan, taman-taman kota dan lain sebagainya. Taman untuk rekreatif pasif adalah taman yang dibentuk agar dapat dinikmati keindahan dan kerindangannya, tanpa mengadakan aktivitas apapun, contohnya: waduk, hutan buatan, penghijauan tepi kali, jalur hijau, dan lain sebagainya. Taman untuk rekreatif pasif dan aktif adalah taman yang bisa dinikmati keindahan sekaligus ada fungsi lain dan dapat digunakan untuk mengadakan aktivitas, contohnya: taman lingkungan. Taman lingkungan adalah suatu taman yang dibuat dan merupakan bagian dari suatu permukiman.

Katagori taman umum (public park) menurut skala pelayanan terdiri dari 4 (empat) katagori yakni: taman nasional (national parks), taman pusat kota (downtown parks), taman lingkungan (neighborhood parks), taman kecil (mini parks). (Darmawan, 2009:48). Taman nasional (national parks) adalah taman dengan skala pelayanan taman ini adalah tingkat nasional, lokasinya berada di pusat kota. Bentuknya berupa zona ruang terbuka yang memiliki peran yng sangat penting dengan luasan melebihi taman-taman kota yang lain, dengan kegiatan yang dilaksanakan berskala nasional. Taman monumen nasional (Monas) di Jakarta merupakan taman nasional. Disamping sebahai landmark kota Jakarta juga dapat sebagai landmark nasional, terutama tugu monumen yang didukung dengan elemen asesoris kota lain seperti air mancur, jalan pedestrian yang diatur dengan pola-pola menarik, disamping taman dan penghijauan di sekitar kawasan tersebut. Taman pusat kota (downtown parks) adalah taman yang berada di kawasan pusat kota, berbentuk lapangan hijau yang dikelilingi pohon-pohon peneduh atau berupa hutan kota dengan pola tradisional atau dapat pula dengan desain pengembangan baru. Areal hijau kota yang digunakan untuk kegiatan-kegiatan santai dan berlokasi di kawasan perkantoran, perdagangan, atau perumahan kota. Lapangan hijau di lingkungan perumahan atau perdagangan/perkantoran di perkotaan merupakan taman pusat kota. Taman Lingkungan 
(neighborhood parks) adalah ruang terbuka yang dikembangkan di lingkungan perumahan untuk kegiatan taman seperti bermain anak-anak, olahraga dan bersantai bagi masyarakat di sekitarnya. Taman di komplek perumahan merupakan taman lingkungan. Taman kecil (mini parks) adalah taman kecil yang di kelilingi oleh bangunan-bangunan, termasuk air mancur yang digunakan untuk mendukung suasana taman tersebut. Taman-taman di sudut-sudut lingkungan/setback bangunan salah satu bentuk taman kecil.

b. Fungsi Taman Kota

Fungsi taman kota sangat besar karena berusaha menciptakan suatu ruang yang manusiawi bagi penduduk kota. Fungsi dari taman kota terdiri dari 3 (tiga) yakni: fungsi sosial, fungsi ekologi dan fungsi estetika (Mulyani, 2006:97.99) .Fungsi sosial dari taman kota antara lain: sebagai tempat melakukan aktifitas bersama; Sebagai tempat komunikasi bersama; sebagai tempat peralihan dan menunggu; sebagai tempat bermain dan berolahraga; sebagai sarana olahraga dan rekreasi; sarana penghubung antara tempat satu dengan tempat lainnya; pembatas diantara masa bangunan; sarana penelitian dan pendidikan serta penyuluhan bagi masyarakat untuk membentuk kesadaran lingkungan hidup; sarana untuk menciptakan kebersihan, kesehatan, keserasian, dan keindahan kota. Fungsi ekologis dari taman kota antar lain: penyegaran udara, mempengaruhi dan memperbaiki iklim mikro, penyerapan air hujan, pengendalian banjir dan pengaturan tata air; memelihara ekosistem tertentu dan perlindungan plasma nutfah; dan pelembut arsitektur bangunan. Fungsi keindahan tanam-taman di perkotaan dengan warna yang alami dan menarik serta tektur yang bermacam-macam dan perencanaan yang teratur akan menampakkan keindahan. Kelebihan ini menjadikan tanaman sebagai salah satu elemen yang dapat menunjang keindahan lingkungan. Karena keindahan merupakan suatu kualitas yang sukar untuk dapat dinilai, duukur, dan ditimbang, tetapi dapat dirasakan dan merupakan suatu nilai yang unik dari dan terhadap seorang, suatu lingkungan, atau suatu karya seni. 
Fungsi ekologi taman kota meliputi: sarana kesehatan, pengaturan iklim, perlindungan, pengaturan penyediaan air tanah, dan penyeimpang alam. Sarana kesehatan tanaman sebagai unsur utama penghijauan dapat mengatur serta membersihkan udara dari polutan-polutan yang ada diudara seperti karbon dioksida, timah hitam akibat dari transportasi, asapasap industri dan lainnya. Karena pepohonan dapat mengurangi polusi, menyerap CO2 dan dalam proses respirasi mengasilkan oksigen yang diperlukan manusia. Taman kota sangat berguna sekali karena unsurunsur taman adalah tanaman, yang dalam fotosintesis akan mengeluarkan O2. Dengan bantuan sinar matahari, tanaman akan menyerap CO2 yang dihasilkan manusia dalam bernafas, dan tanaman mengasilkan $\mathrm{O} 2$ dari proses fotosintesis yang kemudian oleh manusia melalui pernafasan.

\section{c. Faktor-faktor Pengaruh Pemanfaatan Taman Kota}

Faktor-faktor pengaruh pemanfaatan taman kota adalah lahan taman cukup luas, memiliki penghubung hijau diantaranya (biotop interconnection) dengan pinggir alami pada jalan-jalan atau tepi sungai, dilengkapi dengan unsur pembatas dan pengarah seperti pohon peneduh, pagar hijau, aliran air, dan kolam, tonggak, jalur tepi, serta jalan setapak, perkuatan identitas dengan pemilihan jenis pohon peneduh, bentuk, warna, dan bayangan yang berdasarkan pada iklim dan budaya setempat (misalnya; tanjung, asam, gayam dan beringin), kerindangan pohon peneduh harus mampu menaungi tempat duduk, maupun jalan setapak (trotoar), kepedulian terhadap perawatan dan kebersihan serta proses perencanaan melibatkan partisifasi masyarakat karena taman kota meupakan ruang umum yang dimanfaatkan bersama menjadi tanggung jawab bersama pula (Frick, Mulyani, 2006:98), lokasi di kawasan pusat kota dengan bentuk berupa lapangan hijau yang dikelilingi pohon-pohon peneduh atau berupa hutan kota dengan pola tradisional atau dapat pula dengan desain pengembangan baru yang diperuntukan tempat santai (Darmawan,2009:49)

d. Fungsi Taman Kota Sebagai Ruang Publik 
Taman Kota sebagai ruang publik memiliki empat fungsi yaitu: fungsi sosial, fungsi ekologi, fungsi estetika, dan fungsi ekonomi, (Hariyono, 2007; dalam Sukawan, 2012:20). Salah satu fungsi taman kota adalah nilai estitis. Nilai estetis dari taman diperoleh dari bentuk fisik tanaman, tektur tanaman, skala tanaman dan komposisi tanamam. Taman kota sebagai ruang terbuka mempunyai beberapa fungsi sosial. Fungsi sosial pada taman tersebut pada akhirnya mengundang kerumunan orang untuk berdatangan yang kemudian dimanfaatkan oleh masyarakat untuk melakukan kegiatan ekonomi seperti aktivitas pedagang kaki lima (PKL).

\section{OBJEK DAN METODE PENELITIAN}

Dalam Menganalisis Kebijakan Pengelolaan ruang terbuka hijau di kota Makassar, Peneliti menggunakan Metode Penelitian kualitatif. Penggunaan metode ini dinilai tepat untuk menggali fakta dan informasi secara mendalam terhada pengelolaan Taman kota, di Makassar. Penulisan ini bertujuan untuk mengetahui dan mengalisis upaya Pemerintah Kota Makassar dalam mengoptimalkan kebijakan pengelolaan ruang terbuka hijau (RTH) dengan berbagai Stakeholder di Kota Makassar.

Selain itu bagian ini akan menguraikan metode penelitian yang akan digunakan untuk menganalisis masalah yang akan diteliti mulai dari Jenis Penelitian, , Lokasi Penelitian, Informan, Jenis dan Sumber Data,Teknik Pengumpulan Data dan Teknik Analisa Data sebagai berikut :

\section{Jenis Penelitian}

Penelitian ini adalah tergolong pada jenis penelitian deskriptif, sementara pendekatan yang digunakan adalah pendekatan kualitatif. Hal ini dimaksudkan untuk dapat memberikan gambaran atau mendeskripsikan secara sistematis, faktual dan akurat terhadap obyek yang diteliti. Sugiyono (2005:1) Metode penelitian kualitatif adalah metode penelitian yang digunakan untuk meneliti pada kondisi obyek yang alamiah, (sebagai lawannya eksperimen) di mana peneliti adalah 
instrumen kunci, teknik pengumpulan data dilakukan secara triangulasi (gabungan), analisis data bersifat induktif dan hasil penelitian kualitatif lebih menekankan makna dari pada generalisasi. Penelitian deskriptif dengan pendekatan kualitatif bertujuan menggambarkan secara sistematis dan analitik tentang sifat-sifat suatu individu, gejala, keadaan atau kelompok tertentu atau untuk menentukan penyebaran suatu gejala adanya hubungan tertentu antara suatu gejala dan gejala lainnya dalam masyarakat.

\section{Lokasi Penelitian}

Penelitian ini dilakukan di Kota Makassar Provinsi sulawesi selatan. Pemilihan kota makassar sebagai lokasi penelitian dapat dijelaskan sebagai berikut; Kota Makassar merupakan lokasi yang terkena dampak langsung dan merupakan lokasi penelitian yang tepat untuk menemukan jawaban atas pertanyaan tujuan penelitian ini.

\section{Informan}

Pada penelitian kualitatif, peneliti memasuki situasi sosial tertentu, melakukan observasi dan wawancara kepada orang-orang yang dipandang tahu tentang situasi sosial tersebut. Penentuan sumber data pada orang yang diwawancarai dilakukan secara purposive, yaitu dipilih dengan pertimbangan dan tujuan tertentu. Hasil penelitian ini tidak akan digeneralisasikan ke populasi karena, pengambilan sampel tidak diambil secara random.

Informan dan narasumber penelitian ini ialah mereka Pemerintah, swasta, Pengguna Taman dan Media Massa, dalam pengelolaan Taman kota di Makassar. Adapun teknik penentuan informan dalam penelitian ini adalah melalui pendekatan purposive, dan sebagai informan pada penelitian ini ialah:

Adapun teknik pengambilan sampel dalam penelitian ini adalah melalui pendekatan purposive, dan sebagai informan pada penelitian ini ialah: Pemerintah Kota Makassar (Dinas Pertamanan dan kebersihan Kota Makassar). Masyarakat Kota Menetap (Masyarakat IImiah/Perguruan Tinggi,Masyarakat profesional dan Masyarakat umum Kota Menetap), 
Swasta (pengusaha yang memanfaatkan lahan terbuka hijau), Pengguna Taman kota, Media Massa. Jumlah keseluruhan informan pada penelitian ini sebanyak 8 , dengan klasifikasi sebagai berikut : 8 orang sebagai informan Kunci

\section{Sumber Data}

Data-data penelitian diperoleh dari berbagai sumber data guna menjawab permasalahan penelitian, yaitu : data primer dan data sekunder. data primer adalah data yang didapat dari sumber pertama, dan data sekunder data yang diperoleh dari sumber kedua. Sumber data primer didapat dari para informen dan pengamatan langsung di lokasi penelitian. Sumber data sekunder didapat dari data literatur, dan data instansional, yang terkait dengan relasi kuasa pengelolaan taman kota, ruang publik. Data primer yang dibutuhkan adalah data kondisi fisik taman kota saat ini, data kunjungan ke taman kota dan pandangan pengunjung tentang taman kota, dan data pemanfaatan dari Taman Kota Makassar.

\section{Teknik Pengumpulan Data}

Pengumpulan data merupakan langkah yang sangat penting dalam, penelitian karena itu seseoarang penelitian harus trampil dalam mengumpulkan data agar mendapatkan data yang valid. Pengumpulan data adalah prosedur yang sistematis dan standar untuk memeperoleh data yang di perlukan. Pengumpulan data dilakukan melalui observasi langsung dan wawancara,

\section{Teknik Analisis Data}

Teknik analisa data yang dipakai dalam penelitian ini adalah deskriptif kualitatif. Langkah pengolahan data adalah sebagai berikut: Data yang didapat dari observasi di kumpulkan, dan kelompokkan, selanjutnya identifikasi dan akhirnya disimpulkan berupa hasil potensi dan permasalahan. Untuk data yang didapat dari wawancara berupa rekaman wawancara, dinarasikan dan diedit supaya mendapatkan tata kalimat yang baik dan benar. Narafikasi dari hasil wawsancara dianalisa berdasarkan teori dan konsep yang ada, dan selanjutnya disimpulkan. 


\section{HASIL PENELITIAN DAN PEMBAHASAN}

Penelitian ini menunjukkan secara deskriptif bahwa kebijakan pengelolaan ruang terbuka hijau dikota Makassar dapat terwujud secara maksimal apabila semua stakeholders dapat bersinergi dengan baik. Stakeholders yang terlibat antara lain: Pemerintah, swasta, masyraakat dan media massa.

\section{Pemerintah}

Kewajiban pemerintah kota, Dalam hal ini instansi/ lembaga dinas pertamana, dinas pertanian dan dinas kehutanan adalah mengadakan dan menyelenggarakan pembangunan yang adil untuk peningkatan kehidupan masyarakat kota, termasuk didalamnya bidang keamanan, kenyamanan dan keselarasan. Apabila hal ini dikaitkan dengan jenis ruang terbuka hijau yang ada maka ruang terbuka hijau yang harus disediakan oleh pemerintah adalah ruang terbuka hijau koridor yang meliputi jalur hijau kota dan jalur hijau jalan. Ruang terbuka hijau produktif yang meliputi kawasan pertanian kota, perairan/tambak. Ruang terbuka hijau konservasi yang meliputi kawasan cagar alam dan hutan kota. Ruang terbuka hijau lingkungan yang meliputi kawasan taman lingkungan dan bangunan, serta taman kota. Ruang terbuka hijau khusus meliputi kawasan pemakaman, perkantoran dan kebun binatang.

Dalam pengelolan ruang terbuka hijau dikota Makassar pemerintah dalam hal ini melalui dinas Pertamanan dan kebersihan kota Makassar, pertama, melakukan perencanaan, yaitu menyiapkan Bahan Penyusunan Rencana Program dan Petunjuk Teknis di Bidang Pertamanan, dimana Pemerintah kota Makassar dalam hal ini dinas pertamanan dan kebersihan kota makassar menyusun rencana program disesuaikan dengan kebutuhan masyakarat misalnya menyusun program pembuatan joging area,atau sarana rekreasi sebagai tempat masyarakat berkreasi. Secara keseluruhan dalam pengelolaan ruang terbuka hijau khususnya taman kota dikota Makassar perencanaanya sudah dilakukan sesui dengan kewenangan pemerintah akan tetapi belum terlalu maksimal. Kedua, koordinasi , Pemerintah kota Makassar dalam mewjudkan 
optimalisasi pengelolaan ruang terbuka hijau dalam hal ini taman kota melakukan koordinasi dalam dua bentuk yaitu koordinasi internal dan ekternal. kooordinasi secara internal berjalan sesuai dengan tugas dan fungsi Dinas pertamanan dan kebersihan Kota Makassar. hal ini dibuktikan dengan pembagian tugas masing-masing pihak yang ada disetiap taman yang ada di kota makassar. kordinasi internal dilakukan berdasarkarkan struktur organisasi yang ada di dinas Pertaman dan kebersihan Kota Makassar dan koordinasi eksternal dilakukan dengan semua stakeholder baik swasta, masyarakat kota dan media massa. Ketiga kelembagaan, dalam hal mengenai kelembagaan pemerintah kota kota makassar dalam hal ini dinas pertamanan dan kebersihan kota makassar berupaya melakukan harmonisasi kelembagaan dengan lembaga-lembaga lain seperti satpol pp kota makassar dan para pengguna taman. Ke empat, Sosialisasi, tugas pemerintah dalam upaya mewujudkan pengelolaan ruang terbuka hijau ( taman kota ) perlu melakukan sossialisai mengenai taman-taman kota. Dalam hal sosialisasi dinas pertamanan dan kebersihan kota Makassar telah bekerja sama dengan media-media lokal, baik cetak maupun televisi-televisi lokal.

\section{Swasta}

Peran swasta sebagai pelaku ekonomi kota, yang bergerak disektor formal maupun informal, tidak secara mutlak berkewajiban untuk melaksanakan pengadaan ruang terbuka hijau kota. Melalui pertimbangan-pertimbangan tertentu serta pengkajian dari sudut pandang swasta, dapat disediakan ruang terbuka hijau yang memungkinkan untuk dikelola oleh swasta. Yaitu ruang terbuka hijau untuk keindahan/estetika, ruang terbuka hijau untuk rekresai, ruang terbuka hijau lain yang dapat dikomersilkan.

Dalam pengelolaan ruang terbuka hijau (taman kota ) Dikota Makassar dinas pertamana dan kebersihan selalu bekerja sama dengan pihak swasta. pihak swasta selalu berkontribusi dalam hal untuk meningkatkan keindahan taman kota. Pihak-pihak swasta yang sudah terlibat dalam dan bekontribusi dalam pengelolalan ruang terbuka hijau 
dikota Makassar yaitu bank daerah dan bank swasta seperti bank sulselbar, bank danamon, dan bank panin. Kontibusi bank-bank tersebut sesuai hasil pengamatan dan fenomena serta fakta yang ditemukan dilapangan yaitu menyumbang bibit pohon dan dan pot-pot bunga.

\section{Masyarakat Kota}

Peran serta Masyarakat, baik secara individual maupun kelembagaan terhadap ruang terbuka hijau lebih terbatas pada pemanfaatan dan pemeliharaan. Dari segi perencanaan maupun pengadaannya, peran serta masyarakat sangat kecil sekali. Hal ini disebabkan keberadaan ruang hijau kota biasanya terbentuk oleh adanya tanah kosong yang belum/tidak dimanfaatkan. Kelangsungan keberadaannya tidak dapat dijamin, sehubungan dengan sifat penguasaan tanahnya yang lebih banyak bersifat individu (bukan tanah negara).

Pemerintah kota makassar dalam hal ini dinas kebersihan kota makassar selalu melibatkan peran masyarakat dalam hal pengelolaan ruang terbuka hijau. Peran masyarakat kota Makassar dalam pengelolaan ruang terbuka hijau dikota makassar ada yang perduli ada juga acuh tak acuh. Masyarakat yang perduli banyak didominasi dari kalangan masyarakat kampus atau dari perguruan tinggi yang selalu melakukan penelitian kelompok-kelompok masyarakat, LSM penggiat dan pencinta lingkungan. Adapun masyarakat yang acuh tak acuh yaitu pada umumnya didominasi oleh masyarakat yang tidak paham dengan manfaat ruang terbuka hijau seperti anak-anak jalan dan para pengemis kota.

\section{Media Massa}

Media massa baik elektronik maupun Media cetak ikut berperan sebagai pelaku dalam pengelolaan ruang terbuka hijau, khususnya dalam menciptakan opini publik terhadap pentingnya keberadaan ruang terbuka hijau di perkotaan. Di samping hal tersebut fungsi media massa juga bermanfaat mengawasi perkembangan ruang terbuka hijau. Pemerintah kota makassar dalam hal ini dinas pertamanan dan kebersihan kota makassar dalam hal mengoptimalkan pengelolaan ruang terbuka hijau 
(taman kota) sudah bekerja sama dengan media massa baik media cetal atau media elektronik lokal yang ada dikota Makassar.

\section{KESIMPULAN DAN REKOMENDASI}

Hasil penelitian ini dapat disimpulkan Upaya pemerintah kota Makassar dalam mengoptimalisasi kebijakan pengelolaan ruang terbuka hijau dikota Makassar dengan berbagai stakeholders seperti swasta, pengguna taman dan media massa sudah berjalan dengan baik, namun masih perlu ditingkatkan lagi agar fungsi ruang terbuka hijau sebagai fungsi ekologi,fungsi sosial dan fungsi ekonomi dapat terwujud.

Adapun rekomendasi dari penelitian yaitu :

1. Pemerintah Kota Makassar dalam hal ini dinas pertamanan dan kebersihan Kota Makassar harus mampu membuat suatu kebijakan atau legitimasi secara formal kerja sama dengan pihak swasta tentang pengelolaan taman kota Makassar.

2. Menindak para pengguna taman kota dan memberikan sangsi yang tegas kepada penguna taman yang merusak taman kota.

\section{DAFTAR RUJUKAN}

Agustino Leo. 2008. Dasar-dasar Kebijakan Publik. Bandung: Alfabeta Asmuliany, A. 2010. Komparasi Tingkat Pemanfaatan Ruang Terbuka Hijau Di Kota Makassar. Tesis. (Tidak Dipublikasikan), Makassar : Program Pasca Sarjana UNHAS.

Hakim, Rustam. 2010. Ruang Terbuka dan Ruang Terbuka Hijau. Jakarta: Universitas Trisakti.

Handam, H., \& Tahir, M. M. (2016). Peran Pemerintah Daerah dalam Pelaksanaan Penataan Pedagang Kaki Lima di Pasar Minasamaupa Kabupaten Gowa. Otoritas: Jurnal Ilmu Pemerintahan, 6(1), 28-41.

Joga, Nirwono. 2011. RTH30\% Resolusi (Kota) Hijau. Jakarta: PT Gramedia Pustaka

$$
\text { Utama }
$$

Makmur. 2011. Efektifitas Kebijakan Kelembagaan Pengawasan. Bandung : PT Refika Aditama.

Nurmandi, Achmad. 2014. Manajemen Perkotaan: Teori Organisasi, Perencanaan, Perumahan, Pelayanan Dan Tranportasi mewujudkan kota Cerdas. Yogyakarta: JKsG

Sugiyono.2005. Memahami Penelitian Kualitatif. Bandung: Alfabeta 
Sugandhy Aca,Hakim Rustam.2009.Prinsip Dasar Kebijakan Pembangunan Berkelanjutan Berwawasan lingkungan.Jakarta:

Bumi Aksara

Winarno,budi,2002 kebijakan Publik,teori dan proses. Yogyakarta: Media Presindo

JAP. Peran Pemerintah Daerah Dalam Mengelola Ruang Terbuka Hijau Dengan Prespektif Good Environmental Governance (Studi Dikota Madiun) Vol 1 No.3/2012

Undang-Undang Republik Indonesia. Undang-Undang Nomor 26 Tahun 2007 Tentang Penataan Ruang. 